\title{
THE TASMANIAN LEGACY OF MAN AND FIRE
}

\author{
by W.D. Jackson
}

\author{
(with two tables, six text-figures and one plate) \\ JACKSON, W.D., 1999 (31:x): The Tasmanian legacy of man and fire. Pap. Proc. R. Soc. Tasm. 133(1): 1-14. \\ https://doi.org/10.26749/rstpp.133.1.1 ISSN 0080-4703.
}

Departmentof Plant Science, University of Tasmania, GPO Box 252-55, Hobart, Tasmania, Australia 7001.

The vegetation of Tasmania is complex and much of it is in a state of disclimax. At the time of European settlement, the proportion of non-forest open vegetation was $37 \%$, about $5 \%$ of this at high altitudes. In the present interglacial climate, in regions of high rainfall, where rainforest dominance might be expected, approximately $45 \%$ carries sedgeland, grassland, shrub communities and wet sclerophyll forest. Similarly, drier areas carry extensive grassland, sedgeland and heath, instead of dry eucalypt forest. This complexity of distribution and disciimax can be attributed to fire disturbance. Fire not only produces a successional mosaic but, through Ecological Drift, causes extinction of communities. This level of displacement appears to demand a timespan of human-induced fire sufficiently long to affect soil fertility. A palaeontological record of the last five glacial cycles has been analysed from the Darwin Crater in western Tasmania and compared with that from the Chatham Rise, New Zealand. These show parallel behaviour in the proportions of forest and non-forest communities in the earlier cycles. However, the Tasmanian record shows a marked divergence during the Last Glacial cycle, with a twofold increase in open vegetation relative to closed forest. Eucalypt forest increases relative to rainforest, and charcoal increases relative to woody vegetation. These changes occur through a variety of climates, including full glacial and optimum interglacial, but are not apparent in the New Zealand core, making it difficult to attribute them to a climatic cause. In the Tasmanian vegetation, they can be explained by an increase in fire frequency, due to human activity. Since their onset occurs in isotopic oxygen stage 4 and continues in the differing climates thereafter, it may be inferred that the ${ }^{14} \mathrm{C}$ dates of the earliest evidence of occupation by the Aborigines are gross underestimates. A date of about 70000 yrs BP is more likely. It appears that, when using ${ }^{14} \mathrm{C}$ methodology, such underestimation for dates beyond 30000 yrs BP is to be expected in palaeosamples from western Tasmania.

Keywords: disclimax vegetation, fire, Aboriginal occupation, Tasmania.

\section{INTRODUCTION}

\section{The Aborigines}

Anthropological research shows that the Aborigines have occupied Tasmania since the Late Pleistocene. Rock shelter and cave sites, predominantly in limestone valleys across western and southern Tasmania, show occupation dating from $34 \mathrm{ka}$ to about $12 \mathrm{ka}$ (Cosgrove 1995: fig. 16). During this period of largely cool interstadial to cold glacial climates, the present eastern half of Tasmania was apparently too dry for Aboriginal food resources, although the now submerged continental shelf would probably have been extensively utilised. The precipitation of most of eastern Tasmania during the Last Glaciation has been estimated to have been $60 \%$ drier than the present 500-850 $\mathrm{mmyr}^{-1}$ (Markgraf et al. 1986). Palaeontological and pedological evidence shows most of the eastern region to have had a dry-cold desert vegetation of Asteraceae-Chenopodiaceae shrub steppe, with few trees, shifting sand dunes and dry watercourses (Bowden 1983, Sigleo \& Colhoun 1981, 1982, Colhoun 1977, Nicolls 1958). In contrast to the lack of evidence for Aboriginal occupation of the eastern region before $12 \mathrm{ka}$, this region shows abundant evidence of extensive use from early in the Holocene up to the time of European settlement. However, the sites previously occupied in the western region were abandoned and not reoccupied after the beginning of the Holocene.

It appears that the Aboriginal population was not large. Estimates range from one to several thousand (Ling-Roth 1899: 113, Milligan 1858). Most estimates were probably exaggerated because the Europeans only had contact with the Aborigines in the east and on the coasts, where their population was densest.
The information gathered early in European settlement indicated that small family groups operated independently, hunting and food gathering in a truly nomadic fashion with extensive home ranges of about $70 \mathrm{~km}$ (La Billardiere 1800, Ling-Roth 1899). While on the move, they carried fire in the form of smouldering decayed wood or fungus (Ling-Roth 1899; see pl. 1). As a consequence, the vegetation was frequently ignited by accidentally dropped embers.

The Aborigines used fire extensively as a tool, to advertise their presence to others, to flush animals out of cover, to combat enemies and to systematically burn patches of vegetation in a controlled manner to create "green pick" grazing for herbivores, thus ensuring future hunting success. Wet closed forests provided few resources and were avoided, although some so-called "native roads" through forest (Robinson in Plomley 1966) were kept open to provide access to hunting grounds. As a consequence of its extensive forested regions, western Tasmania, apart from the coastal fringes, received little use by the Aborigines during the Holocene, and the large expanse of sedgeland in the inland southwest was also sparingly utilised, presumably because of the low animal productivity.

\section{The Environment}

General short descriptions of the Tasmanian environment are available (Jackson 1981a, 1998b). The factors which control the interactions of fire and vegetation may differ from those pertaining to mainland Australia and, therefore, are described here.

The climate of Tasmania is dominated by its position at latitude $40^{\circ}-43^{\circ} \mathrm{S}$ on the northern edge of the southern zonal wind system, the Roaring Forties. Since only about 


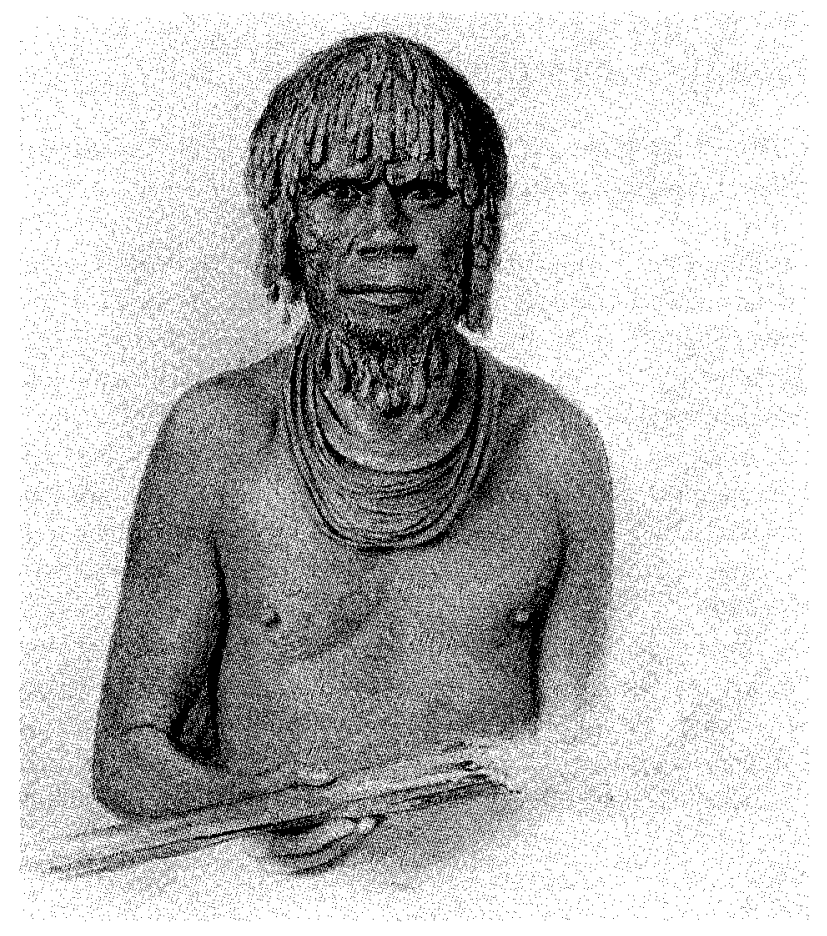

PLATE 1

A Tasmanian Aborigine holding a fire stick (after Bock) (Ling-Roth 1899)
4\% of the Earth's surface at this latitude is land, the lack of continentality provides a strong and dependable marine influence. By Northern Hemisphere standards, the seasons are merely an alternation of extended spring and autumn. As a result of the strong westerly bias in the wind impinging on the mountainous terrain in the western and northeastern regions (which present altitudes of $900-1500 \mathrm{~m}$ ), there is a strong gradient in precipitation from 1500-3000 $\mathrm{mmyr}^{-1}$ in the west to $<500-850 \mathrm{mmyr}^{-1}$ in the east (fig. 1). Reliability is high in the west, deviating only $<10-14 \%$ from the mean average, while in the eastern half deviations of 16->20\% are found (Scott 1956). Due to the seasonal movement of the belt of zonal wind, the northwestern quarter tends to partially escape this in summer-autumn, so that a two-season dry, two-season wet pattern develops, with about $50 \%$ of the seasonal divergence common to southeastern Australia. In the southwestern quarter, there is a marked movement to a uniform seasonal distribution, with only summer showing a 5\% deviation (Jackson 1998b).

Evapotranspiration levels in the eastern half are high, due to the windy environment and high radiation load (Nunez 1978). The aspect effect is very strong in Tasmania, due to the latitude. Holland \& Steyn (1975) estimated the difference in radiation levels between equatorial and polarfacing slopes of $30^{\circ}$ to be equivalent to a shift of $20^{\circ}$ in latitude. This effect contributes much to the mosaic distribution of vegetation types and the incidence of fire. Precipitation/evaporation ratios range from $4: 1$ in the west to $<0.5$ in the east. Through the marine influence, permanent snow does not exist and snow lie is ephemeral. Extended periods of low temperature are rare, even on the considerable areas $(-5 \%)$ of inland high country between 800 and $1200 \mathrm{~m}$. As a result, a treeline is difficult to define at any one altitude, and trees (especially rainforest spp.) ascend to altitudes $>1000 \mathrm{~m}$, gradually assuming shrubby forms. Inverted treelines occur inland largely due to the combined influences of fire and frost.

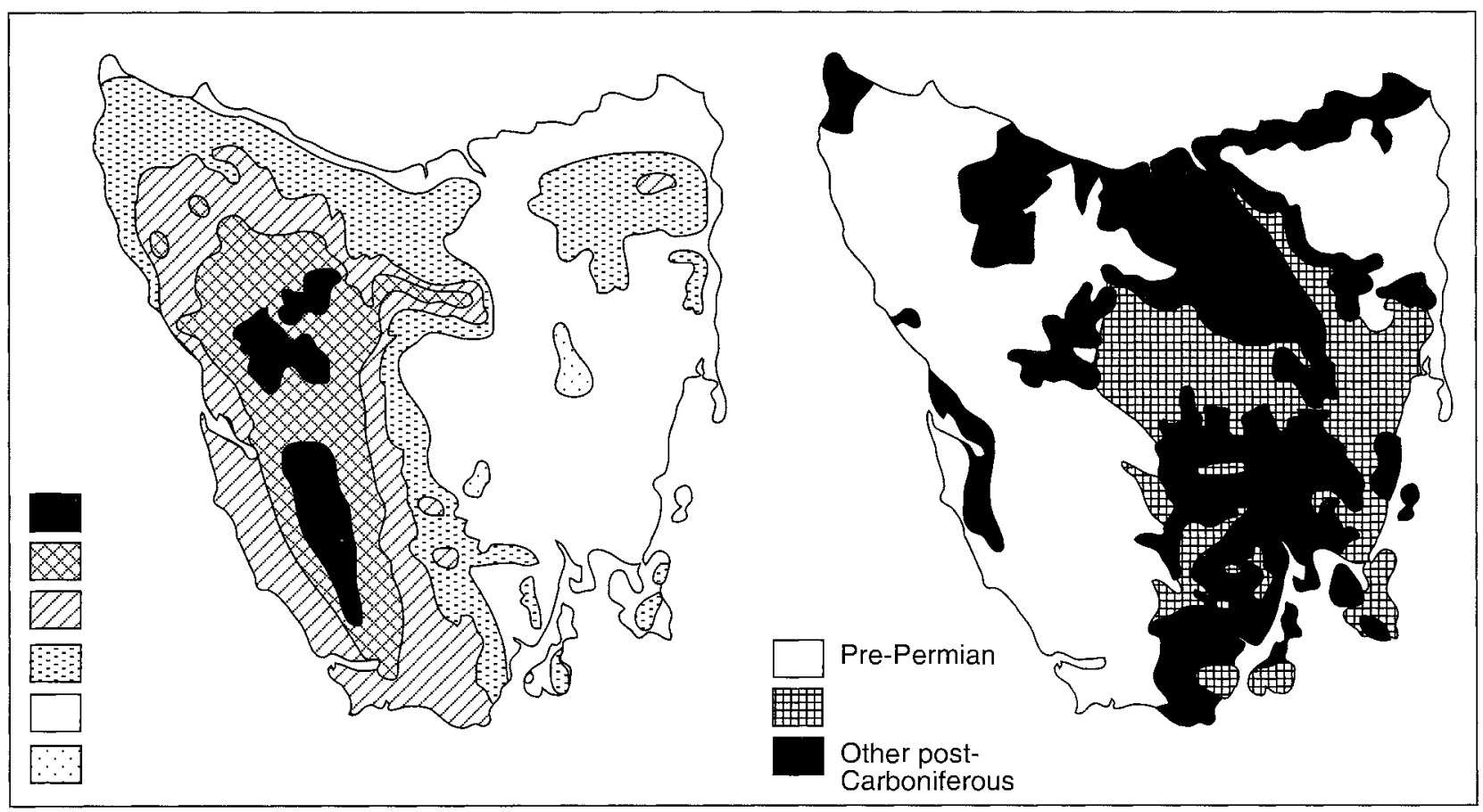

FIG. 1 - The general pattern of precipitation and geological exposure simplified from several sources. 


\section{ROYAL SOCIETY OF TASMANIA \\ Papers and Proceedings \\ Volume 133, Part 1 \\ ERRATUM}

The loss of some text within Figure 1 on page 2, present in an early proof, was not detected prior to printing.

Herewith a correct version of the figure.

M.R. Banks, Hon. Editor

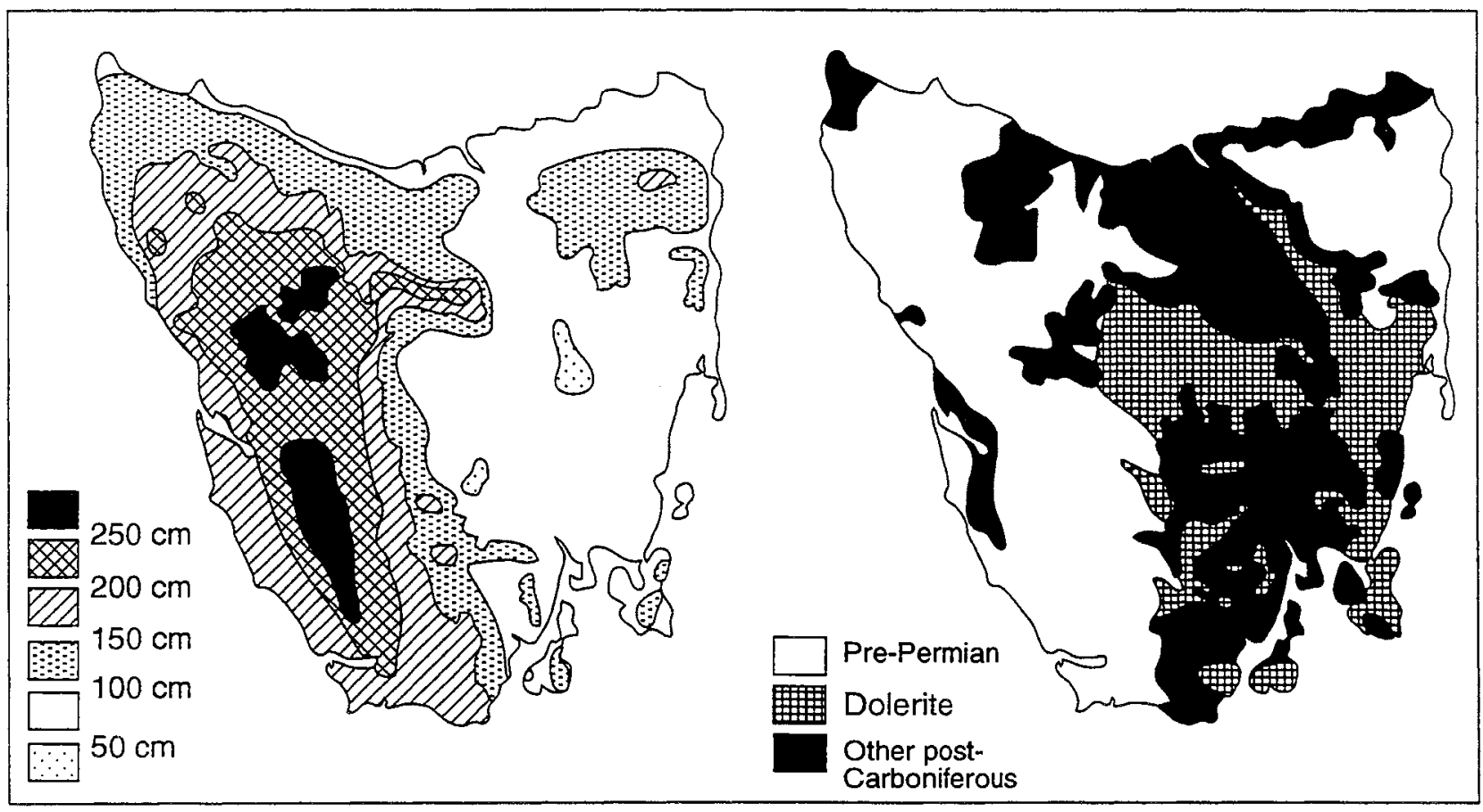

FIG. I - The general pattern of precipitation and geological exposure simplified from several sources. 
The annual weather pattern is dominated mostly by a succession of cold fronts embedded in the westerly air stream, bringing rapidly fluctuating temperature and precipitation. Fronts move rapidly, often more than $1000 \mathrm{~km} \mathrm{day}^{-1}$, transverse to the strong pressure gradients which occur between the slow-moving cells of high pressure, usually centred over middle Australia, and the rapidly moving low-pressure cells of the high $40^{\circ} \mathrm{S}$ latitudes. In summer, during February-March, when the zonal belt moves south, high-pressure cells are occasionally centred just east of Tasmania; approaching cold fronts cause highpressure gradients, bringing strong winds of very hot, dry air from inland Australia. This causes extreme fire danger conditions: maximum temperatures $37^{\circ} \mathrm{C}$, relative humidity $<10 \%$, average wind speed $50+\mathrm{km} \mathrm{hr}^{-1}$, maximum gusts $>95 \mathrm{~km} \mathrm{hr}^{-1}$, equivalent to drought factor 9 . Such conditions generally occur for one or two days each summer, usually producing a rash of forest wildfires. However, when the vegetation is already in a state of drought, very serious wildfires occur. Such recurrent drought conditions appear to be based on an 11-year cycle. This pattern is disturbed by the El Nino southern circulation effect, which appears to move the belt of zonal winds further south (Jackson $1999 \mathrm{~b}$ ), reducing the strength of the westerly stream.

The incidence of fire in Tasmania is overwhelmingly due to human activity. Lightning-induced fire is rare, unlike in mainland Australia. An analysis of the wildfire records shows that the incidence of fire resulting from lightning strikes is very small $(0.01-0.1 \%$ of cases) and the area thus burnt is also comparatively small $(<0.01 \%$ of the total), since rain usually accompanies electrical storms in Tasmania
(Jackson \& Bowman 1982, Ingles 1985). Many fires are already burning when the extreme fire danger conditions arise.

Once a forest fire in Tasmania gains a sufficient front in severe conditions, the fire storm creates strong convection updrafts, which carry burning bark and branches to high altitudes. Burning embers carried downwind create a contagion of spot fires fot distances of up to $60 \mathrm{~km}$ (Cheney 1981). A detailed analysis of past fires based on records and on tree ages (Marsden-Smedley 1998a, b) shows that severe fires have occurred more than six times in the last 200 years. Two of these fires, in $1898 / 99$ and $1933 / 34$, each burnt 15 to $20 \%$ of the island.

\section{VEGETATION}

\section{Fire and Geological Influences}

The current vegetation of Tasmania has been accurately mapped (Kirkpatrick \& Dickinson 1984, R.F.A. 1996). Figure 2 provides a simplified version of Kirkpatrick and Dickinson's map (Duncan 1990). Short descriptions of the vegetation types were given by Jackson $(1965,1981 \mathrm{~b}$, 1999a) and detailed studies provided in (Reid et al. 1999). The following notes deal with those aspects important to an appreciation of past and present effects of fire.

Table 1 shows the relative areas of the major vegetation types: the proportion estimated to have existed in 1800 , the proportion at present, and those for the northwestern and southwestern quarters, the average fire-free interval

TABLE 1

Major vegetation types

\begin{tabular}{|c|c|c|c|c|c|c|}
\hline $\begin{array}{l}1 \\
\text { vegetation cype }\end{array}$ & $\begin{array}{c}2 \\
\text { pre-European } \\
\%\end{array}$ & $\begin{array}{c}3 \\
\text { present }^{\dagger} \\
\%\end{array}$ & $\begin{array}{c}4 \\
\text { northwest }^{\ddagger} \\
\%\end{array}$ & $\begin{array}{c}5 \\
\text { southwest }^{\$} \\
\%\end{array}$ & $\begin{array}{c}6 \\
\text { fire-free } \\
\text { interval }^{¥} \\
\text { yrs }\end{array}$ & $\begin{array}{c}7 \\
\text { combustible } \\
\text { fuel }^{9} \\
\text { tha }\end{array}$ \\
\hline rainforest & 9.8 & 8.5 & 26.2 & 19.5 & $150-300$ & $25-30$ \\
\hline swamp forest & 0.6 & 0.2 & 0.2 & - & $100-200$ & $20-30$ \\
\hline wet sclerophyll & 19.2 & 14.6 & 24.9 & 15.7 & $80-150$ & $180-320$ \\
\hline dry sclerophyll & 43.1 & 23.1 & 2.1 & - & $20-80$ & $20-30$ \\
\hline grassland & 1.3 & 0.8 & 1.1 & - & $10-25$ & $4-8$ \\
\hline heathland & 6.4 & 3.4 & 1 & - & $10-30$ & $10-20$ \\
\hline alpine & 1.7 & 1.7 & 3.2 & 4 & $100-250$ & $10-15$ \\
\hline saltmarsh & 0.06 & 0.05 & - & - & $\infty$ & - \\
\hline wetland & 0.4 & 0.2 & - & - & $40-80$ & $2-4$ \\
\hline sedgeland & 17.4 & 17.2 & 27.4 & 56.2 & $20-40$ & $10-30$ \\
\hline total $\%$ & 100 & 70 & 86.2 & 95.4 & & \\
\hline cleared land \% & - & 30 & 13.8 & 4.6 & & \\
\hline area, millions ha & 6.62 & 6.62 & 1.34 & 1.23 & & \\
\hline
\end{tabular}

* Estimated relative to the whole state of Tasmania (Kirkpatrick et al. 1995). The figure quoted for dry sclerophyll included large areas which, in 1804, were open grassland or open savannah.

${ }^{\dagger}$ Relative to whole state (Kirkpatrick et al. 1995).

¥ West of Forth River to Mt Manfred (estimate from Kirkpatrick \& Dickinson 1984).

$\$$ Protected region (modified after Marsden-Smedley 1998, after allowance for impoundments and roads).

₹ Average interval between consecutive fires (Jackson 1968).

Average quantity of combustible fuel at time burnt (compiled from a number of sources). 
and the average combustible fuel load when burnt by wildfire.

The essential proportional distribution of these vegetation types has suffered little change since European settlement (table 1). When the free settlers arrived, they found the eastern half of the island with extensive open savannah grassland tracts in the Midland graben and other major valley systems. These tracts were rapidly taken up, since little or no clearing was necessary to start a grazing enterprise. It is clear that the openness of the vegetation was the product of patch-burning by the Aborigines (Jackson 1965, Fensham 1989). The western half of Tasmania, with its dense forests and peaty sedgelands, was left untouched by early settlers except for the exploitation of Huon Pine at Port Davey and Macquarie Harbour. The Van Diemans Land Company made an attempt to utilise the grasslands developed by the Aborigines in the wetter regions of the northwest, but this was not successful, due to the cold, wet climate.

This denser forested region in the west was not opened up until after 1870 , when mineral discoveries due to prospecting initiated extensive firing of the vegetation. Land clearing of the productive soils in the northwest occurred late in the 1800 s with the use of ringbarking and fire. The present extent of cleared land (30\%) was taken mainly at the expense of eucalypt forest along the northern hinterland in the early $1900 \mathrm{~s}$, following very extensive wildfire in $1898 / 99$.

The proportionate differences in the distribution of vegetation types in regions is not merely a response to precipitation (fig. 1). Although the eastern half is much drier and contains virtually all of the dry sclerophyll forest and most of the grassland and heaths, it has withstood the constant firing practices of the Aborigines during the Holocene remarkably well. This can be attributed to the fire-tolerant attributes of the sclerophyll species, especially the eucalypts, and to the clay-rich soils of most of the region. Sills of dolerite cap most of the topographic high points in post-Carboniferous rocks of the eastern half. The dissemination of clay-forming minerals from the dolerite by erosional forces has resulted in soils with a moderate to high cation-exchange capacity. This buffers many soils in the region against leaching losses after fire (Boerner 1982).

Although the western half has been little utilised in the Holocene by the Aborigines, the vegetation appears to show far greater effects of modification by fire, particularly in the southwestern quarter. The considerable differences in the proportionate distributions between the southwestern and northwestern quarters (table 1), although they both receive similar precipitation levels, can be attributed to geological influences in soil genesis. While most of the western region has pre-Carboniferous rocks exposed, the elevated plateau region north of the Pieman River carries remnants of a thin Tertiary basalt cover over much of the highly quartzose Precambrian metamorphic sediments. Erosional processes have distributed the clay-forming minerals from this basalt, from the dolerite on the western fringe of the Central Plateau to the east, and from Cambrian volcanic exposures. As a consequence, most of the valleys here have moderately fertile soil compared to the southwest, with a cation-exchange capacity sufficiently high to resist leaching following fire. The regions with a residual basaltic cover carry krasnozem soils and support extensive forests of callidendrous, tall, closed canopy Nothofagus rainforest
(Jarman \& Brown 1983, Jackson 1983). Exposures of Precambrian quartzitic sediments and some highly quartzose Cambrian sediments have infertile soils supporting implicate or broken canopy rainforest, scrub and sedgeland.

There are few sources of clay minerals in the southwest. The predominant geological exposure is of highly quartzose, metamorphic Precambian sediments. Smaller regions of Cambrian, Ordovician and Devonian-Silurian rocks occur in anticlines, where limestone and sandstone are often covered with quartzitic glacial till and outwash gravels.

The soils of the southwest are, in general, acid and highly organic with a low cation-exchange capacity (Maclean 1979, Bowman et al. 1986). Very few patches of tall, wet forest exist, reflecting the general low level of fertility. A few patches of climax callidendrous rainforest occur in the Boyd River catchment on aspects highly protected from fire, even on Cambrian quartzwacke sediments with no clay in the soil profile. It is certain that such patches have not been burnt for well over 500 years. The biomass has apparently been developed on accumulated nutrients derived from cyclic salt in the precipitation, demonstrating that the climatic climax can be achieved, albeit rarely, on extremely infertile geological substrate, provided that fire does not occur (Harwood 1972, Jackson 1977). Most rainforest in the southwestern quarter is implicate or broken canopy forest (Jarman \& Brown 1983, Jackson 1983) and demonstrates signs of fire disturbance. The wet sclerophyll forests in the southwest are predominantly Eucalyptus nitida. wet mallee woodlands rather than forests. Probably only about $20 \%$ of the wet sclerophyll is tall forest occurring on fire-protected polar aspects.

The predominant vegetation in the southwest, especially on Precambrian quartzites, is a sedgeland heath dominated by Gymnoschoenus sphaerocephalus with mosaic patches of wet scrub of Leptospermum/BaueralAgastachys on water courses and other fire-protected habitats. The soils, although highly organic muck peats, are extremely infertile, with cation-exchange capacities $<20 \%$ (Maclean 1979, Bowman et al. 1986). The low fertility is maintained by the average short fire-free interval of $25-40$ years over the southwestern region.

\section{The Disclimax State}

As the vegetation map (fig. 2) demonstrates, the distribution of the vegetation is a complex mosaic of community types. The almost complete dominance of all but the most alpine sites by forests, as expected on the basis of a climatic climax for such an insular climate, does not occur. In contrast with this expectation, much of Tasmania carries a mosaic of disclimax vegetation, with extensive areas of grassland, sedgeland, heath and scrub. Also, large areas of forest dominated by eucalypts occur in environments which climatically should be the exclusive domain of rainforest.

The amount of open, non-forest land appears to be inexplicably high, given the levels of natural wildfire. The proportion of open, non-forest vegetation existing in 1800 has been estimated (table 1) by adjusting the present distribution of vegetation types on the basis of historical records of land acquisition and clearing (Kirkpatrick et al. 1995). This shows that, at the time of European settlement, the proportion of open, non-forest vegetation was about 37\%; of this about $5 \%$ occurred in alpine or high plateau regions (table 1). 


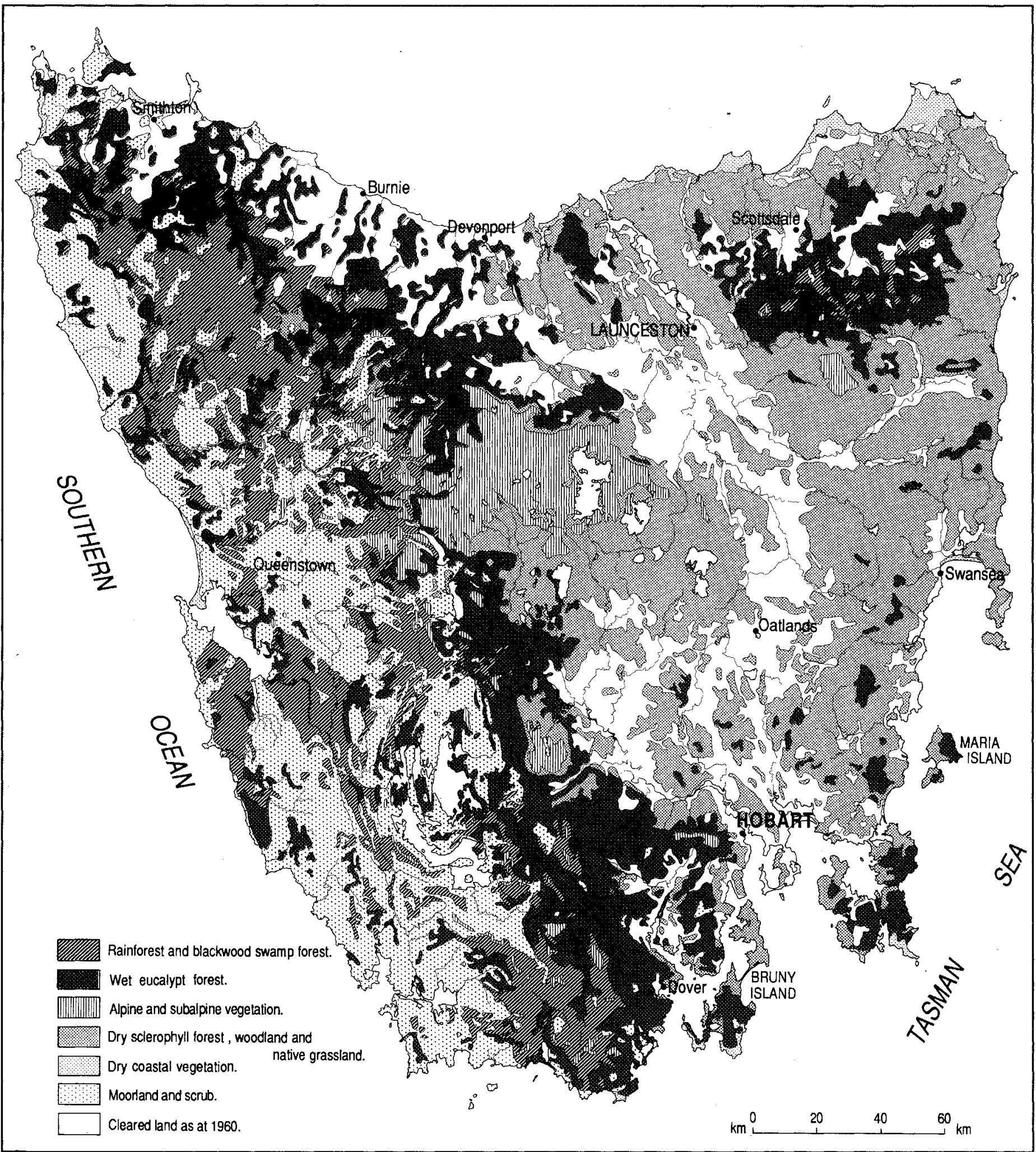

FIG. 2 - The vegetation, simplified after Kirkpatrick or Dickinson (1984) by Duncan (1990).

A few regions where the vegetation is climax or nearly so show every indication of having recently reached that state; for example, the forests of the lower Florentine Valley before 1934 (Gilbert 1959) and the absence of old trees in closed Nothofagus forests on the Guildford Plateau (Jackson 1965). These young forests generally only occur on good, productive soils and/or where their protected location limits the frequency of fires (Jackson 1965). They appear to have colonised previous grassland since European settlement.

This disclimax condition is not entirely due to our present exploitive society, as it was evident before European settlement. In the absence of fire produced by humans, a very different pattern of vegetation would have existed, as the following outline suggests. 


\section{A Hypothetical Distribution of Vegetation for the Holocene in the Absence of Humans}

\section{High rainfall regions (precipitation > $1200 \mathrm{mmyr}^{-1}$ )}

In those regions where precipitation exceeds $1200 \mathrm{~mm}$ per annum, over $40 \%$ of the area, at the time of European settlement, carried disclimax vegetation such as grassland, sedgeland, heath, scrub and eucalypt forest, al though most of the latter was mixed with Nothofagus (Jackson 1968, Brown \& Podger 1982a). The climax vegetation expected on all aspects and in all but the most extreme alpine habitats would be Nothofagus rainforest. This is demonstrated by the rapid capture of Poagrassland communities on the Guildford Plateau by Nothofagus (Jackson 1965); the demise of eucalypt communities on the northeastern highlands (Jackson 1968, Ellis 1986) following their rapid invasion by Nothofagus forest; the successional movements to rainforest, even on soils of low nutritional status (Brown \& Podger 1982b); the presence of patches of callidendrous rainforest in the upper Boyd river catchment, growing on extremely infertile Cambrian quartzwacke sediments and apparently totally dependent on cyclic salt input (Harwood 1972, Jackson 1977). In this hypothetical state, there would be some lightning-induced fires destroying patches of forest. However, the Nothofagus dominance in these burnt patches would return in one generation of the seral forest tree Acacia melanoxylon which has a lifespan of 90-110 years (Gilbert 1959). Since the prevalence of lightning-induced fires is very small in Tasmania $(0.6 \%$ incidence and $0.01 \%$ in area in comparison with man-made fire at present - Jackson \& Bowman 1982, Ingles 1985), the amount of disclimax vegetation would have been insignificant in the absence of mankind.

Medium rainfall regions (precipitation 800-1200 mmyr $^{-1}$ ) In the marginal regions of precipitation, for tall, closed wet forests, two distinct forest communities would prevail, due to the light limitation of the seedling stages of sclerophyll communities and the water limitation of rainforest regeneration (Read 1985, Jackson 1981c, Jackson \& Brown 1999). Their distribution would be dictated by the very strong aspect effect (Holland \& Steyn 1975).

The present intergrading of many vegetation types would not occur. In the absence of frequent fires, the boundaries between the Nothofagus-dominated rainforest communities on the polar aspects and the Eucalyptus-dominated sclerophyll communities on the equatorial aspects would be sharp without much intergradation. This is determined by the requirements of the seedling stages of the two communities. Sclerophyll seedlings cannot tolerate the shade cast by Nothofagus communities, and Nothofagus communities are unable to compete with eucalypts and other sclerophylls under the conditions of limited water availability on equatorial-facing aspects (Read 1985, Jackson 1981c, Jackson \& Brown 1999). Therefore, in the absence of frequent fires, the boundaries between the communities would be sharp and the present intergrading would not occur. Since eucalypts require fire disturbance at intervals throughout their lifespan (maximum 300 years) the extensive forests of wet sclerophyll seen today in regions with precipitation $1000-1500 \mathrm{~mm}$ would be replaced by closed Nothofagus rainforest (Jackson 1981b, Jackson \& Brown 1968). The probabilistic argument of the Ecological Drift theory (Jackson 1968) suggests that eucalypts could not survive long-term in such conditions without manmade fire.

Low rainfall regions (precipitation $<500-850 \mathrm{mmyr}^{-1}$ )

In the low-rainfall regions of the east, the vegetation would be an almost complete forest cover of sclerophyll. Evidence for this derives from the successional stages following fire.

Eucalypts are highly adapted to fire and, in habitats where rainforest species are restricted by the availability of water, continuous regeneration of eucalypts is always possible, due to the availability of light for seedling growth (Read 1985). A number of species have evolved within the genus, each having a competitive advantage in particular environmental niches of water availability, drainage, nutrition, frost etc. (Reid \& Potts 1999). For example, the savannah grasslands of the Midlands region were clearly a product of burning practices by the Aborigines (Fensham 1989). Extensive regions on both margins of these communities have been captured by pole stands of open eucalypt forest since European settlement (Duncan 1990, Jackson $\&$ Brown 1999). Frost and grazing pressures slow the encroach of forest, but it is clear from the relationship of forest type to the dryness index that forest will prevail (Nunez 1978). Narrow corridors of rainforest communities would exist in gullies and in very protected polar-facing aspects, largely dominated by Atherosperma, although some areas of Nothofagus dominance would occur. For example, a number of patches of rainforest occur in regions of Tasmania with annual precipitation less than $800 \mathrm{~mm}$. All are on fire-protected southeastern aspects, such as Kempton Tier (annual precipitation $\mathrm{P}=505 \mathrm{~mm})$, Dromedary $(\mathrm{P}=$ 665), Maria Island $(P=656)$ and Lake Leake $(P=800)$. Extensive gully communities of Olearia and Bedfordia would extend to the coastal fringe (Jackson 1983). The general cover in the areas with rainfalls less than about $800 \mathrm{~mm}$ would be eucalypt forest, which would be far more uniform than at present in terms of species distribution and age structure. With very low fire-frequencies, none of the present patchwork of open or semi-open communities, such as heath, sedgeland and grassland savannah, would exist. The present survival of heaths is due to the high rate of firing in these communities (Jackson 1968). Most occur on sandy or duplex soils, where nutrition is limited and other conditions, such as drainage, often contribute to slow growth-rates of woody plants. The frequency of fire increases the leaching and prevents the accumulation of nutrients, maintaining a cycle of early successional stages.

Various alternatives to the universal dominance by Eucalyptus species in the near absence of fire have been suggested (Withers \& Ashton 1977). It is probable that, in the virtual absence of fire, in some regions Allocasuarina forests would dominate and Callitris in others (Brown \& Bayly Stark 1979, Harris \& Kirkpatrick 1991).

\section{Open areas}

The open grassland savannah of the Midlands and other larger valley systems was a product of high fire-frequency imposed by the Aborigines (Jackson 1965, Fensham 1989), as was the higher altitude grassland on the MiddlesexHampshire and Mathinna plains. It is incorrect to attribute the openness of these and other areas to European development (Jackson 1965, 1981a, Bowman \& Brown 1986, Ellis 1986). Hellyer in 1827 , reporting on the country around Valentines Peak (Bishoff 1832), stated: 
Fine open country to NE and SW - grassy hills and knolls 1000-1500 acres in a patch and without a tree except for a few clumps of Blackwood - kangaroo were here in abundance as in every part of the country about - proceeding SW passed through excellent country consisting of gently rising, dry grassy hills. On the following day walked over many considerable hills the grass of which had recently been burned by the natives.

\section{ECOLOGICAL DRIFT}

It has previously been argued (Jackson 1968) that the disclimax state of the vegetation is the product of a long history of recurrent fire produced by human activity. Jackson proposed that

- complex interactions between vegetation, soil and fire vie with climate in controlling the genesis of both soil and vegetation (fig. 3B);

- variation in the interval between two successive fires, by interruption of regenerative processes described by Noble $8 x$ Slatyer (1981) as a disruption of the flow of vital attributes, could produce sudden changes in the type of vegetation;

- each community type has a statistically variable distribution of the fire-free interval, ranging in central tendency, variance and skewness:

- reproductive cycles of characteristic species could be terminated by fires at large deviations from the central tendency.

The continuance or otherwise of mixed forest (Gilbert 1959), where an open stratum of tall, wet sclerophyll eucalypts stands over a closed canopy of rainforest, will illustrate these processes.

The first fire kills all trees. Both eucalypts and rainforest regenerate from seed. The original eucalypt regeneration reproduces after about 20 years.

(1) If the second fire occurs before about 20 years, all trees are eliminated and the forest is replaced by seral open vegetation of herbs, sedges and ferns.

(2) If the second fire occurs between 20 and 40 years, rainforest species will be eliminated and the mixed forest reverts to wet sclerophyll forest.

(3) Fire after the rainforest has matured regenerates mixed forest.

(4) If the period between the two fires exceeds about 350 years, the eucalypts will be eliminated, because eucalypt seedlings cannot survive in the low light intensity under the rainforest canopy. As a result, the mixed forest is converted to pure rainforest.

The process was termed "Ecological Drift" because of its similarity to genetic drift. Empirical distributions for the probability of the fire-free interval for the various types of vegetation were determined by the assessment of plant age on a large number of sites. These are shown in figure $3 \mathrm{~A}$ with the projected drift movements. The process of drift is reversed by normal successional processes. However, there are obvious trends towards communities with vegetative means of reproduction, which can tolerate short fire-free intervals. These can increase the probability of "sinks", if soil fertility is also decreased by leaching or volatile loss after fire.

It is not possible to show experimentally the validity of the Drift argument. The boundaries between vegetation types at present seem remarkably stable. Even after extensive wildfire, most communities re-established on their original habitat with but minor boundary changes. The apparent stability of these boundaries led Mount $(1979,1982)$ to propose a theory of "Stable Fire Cycles". In contrast to the Ecological Drift concept, the Stable Fire Cycle theory assumes that the incidence of fire in a community is almost constant, because it is dependent on the particular rate of fuel accumulation of the community (table 1), and that the possibility of ignition is almost constant. The incidence then depends on sufficient fuel accumulation.

Much debate has taken place regarding the relative validity of the two theories (Macphail 1980, Bowman \& Jackson 1981, Mount 1982, Jackson \& Bowman 1982). Markov simulations by Henderson \& Wilkins (1975) and later adjustments (Brown \& Podger 1982b) supported the projections of the Ecological Drift theory. The intervals between fires in five structural forms of vegetation at Bathurst Harbour and at Hogs Back in the Lune River catchment are in broad agreement with the predictions of the Ecological Drift model. Recurrent fires by Europeans have converted implicate rainforest to Gymnoschoenus sedgeland at Hogs Back in $<100$ years (Brown \& Podger 1982a, c, Podger et al. 1989).

The Ecological Drift paper (Jackson 1968) was written when the accepted period of human occupation of Tasmania was $10-12 \mathrm{k}$ yrs. The present history of occupation, extending to at least $34 \mathrm{ka}$ (Cosgrove 1995: fig. 16), makes the Drift argument more credible. However, because of the apparent static nature of the community boundaries at present, it is still difficult to understand how such extensive areas of disclimax vegetation could arise in even $34 \mathrm{k}$ yrs. Changes to the physical structure of the soil and its fertility seem even less likely to have occurred within this timespan.

\section{GEOLOGICAL EVIDENCE}

\section{Palaeoclimates}

The past oscillating sequences of climates during the Quaternary (Colhoun \& Fitzsimons 1990, Kiernan 1989, Jackson 1999c) have resulted in corresponding sequences of vegetation change, as treelines shifted up and down $1000 \mathrm{~m}$ in altitude, and cold, arid shrub steppe-grasslands alternated with humid forests (Macphail 1979, Kirkpatrick 1986, Jackson 1999c). It is apparent that the altitude range and rugged topography, plus the availability of a wide continental shelf and bridging connection to mainland Australia, permitted refuges for species in most climates, humid or arid, warm or cold. Each climate soon established a stable vegetation, due to the persistence of species but not communities, through change.

The length and intensity of the glacial-interglacial episodes differed, presumably due to interaction between the various components responsible for orbital forcing. Temperature and precipitation varied sufficiently to produce differing vegetation responses in both glacial and interglacial climates. Each period of rapidly changing climate produced equally rapid changes in vegetation, resulting in restructured plant communities. Based on analysis of pollen diagrams of the last four glacial cycles $(350 \mathrm{k} \mathrm{yrs}$ ) from the Darwin Crater (Colhoun \& Van de Geer 1988, 1998, Colhoun 1989), the estimated average response time of the vegetation to a full transition of the climate from glacial to interglacial conditions is about $2.7 \mathrm{k}$ yrs; the response time of the 

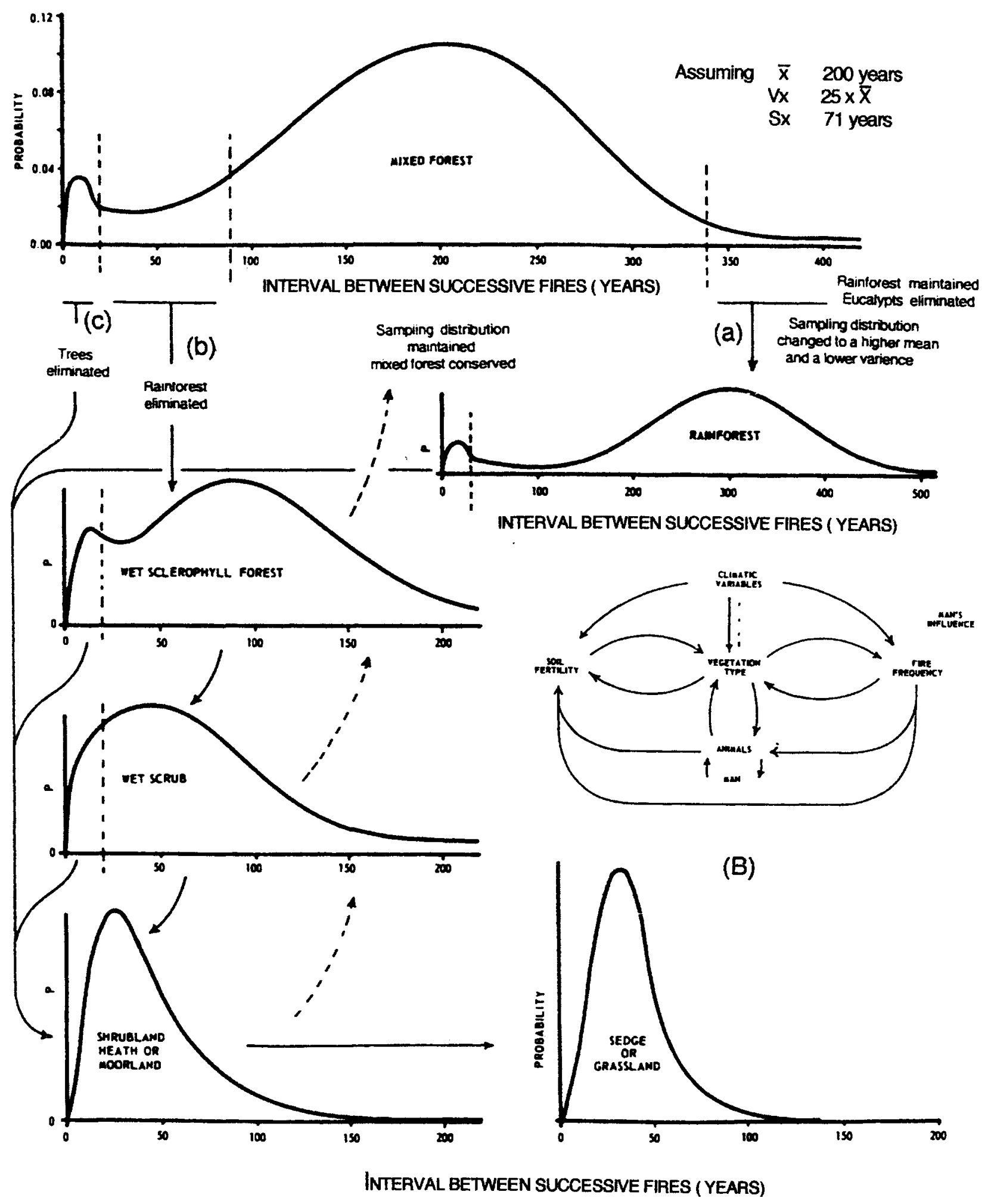

(A)

FIG. 3 - (A) Ecological Drift, a diagrammatic interpretation of progressive shifts in likelihood of vegetation types and their associated fire frequencies. It is assumed that drift in the sampling distribution occurs through chance occurrences of short or long intervals between two successive fires. Broken arrows indicate long-term climatic succession. Chance long intervals (>300 yrs) lead to the elimination of eucalypts. This causes a lowering of the fire risk in future generations of forest (a). Chance short intervals $(20-40 \mathrm{yrs}$ ) lead to the elimination of rainforest (b), or (if $<20 \mathrm{yrs}$ ) of all forest species (c), with a consequent shift to sampling distributions with lower mean fire-free intervals. This increases the probability of drift to degraded open vegetation with a high fire frequency, a process which is accelerated on poor soils because of vegetation-fire interactions with associated increased loss of nutrients through sublimation and leaching. (B) Vegetation-fire-soil interactions and human input. 
reverse change from interglacial to glacial is marginally shorter at about $2.5 \mathrm{k}$ yrs. About $80 \%$ of the transition occurs in less than $20 \%$ of these full transition times, i.e. in 500-600 yrs. This would approximate two generations of dominant trees. The early periods almost certainly produced bursts of evolutionary activity, extinction of species and emergent new forms.

The varied pattern of climate in Tasmania over the later Quaternary, as reflected in the vegetation, is illustrated by the pollen profile from the Darwin Crater in the Andrew River valley, western Tasmania $\left(42^{\circ} 19^{\prime} \mathrm{S}, 145^{\circ} 39^{\prime} \mathrm{E}, 180 \mathrm{~m}\right.$ a.s.I.). This crater was formed by a meteorite impact (Ford 1972) c. $700 \mathrm{ka}$ (Gentner et al. 1973, Fudali \& Ford 1979). The subsequent lake has been infilled by sediment from surrounding forests (Colhoun \& van de Geer 1988, 1998, Colhoun 1989). The provisional summary of the upper $20 \mathrm{~m}$ of this core of $63 \mathrm{~m}$ depth (Colhoun $\&$ van de Geer 1998) is reproduced in figure 4A, where the pollen sums of the major categories of rainforest, trees and shrubs, and alpine shrubs and herbs are shown as a percentage of the total pollen sum. Aquatic and swamp taxa have been excluded from this sum. The sums were obtained from the analysis of pollen in samples from $100 \mathrm{~mm}$ long consecutive sections of the core in depth. There are, unfortunately, four breaks in the core, one of which removes much of the evidence in the last interglacial. On the basis of the relative proportions of the major categories of the vegetation, Colhoun \& van de Geer (1988) divided this $20 \mathrm{~m}$ section of the core into ten zones of inferred climate corresponding to the oxygen isotope stages, showing five cold, dry and five warm, wet periods. The diagram illustrates the repeated pattern of forest expansion and contraction, typifying the major zones. It also demonstrates the variability within each major zone, as typified by the subzones defined by Colhoun \& van de Geer (1998).

A deep-sea sediment core taken on the Chatham Rise, $250 \mathrm{~km}$ off the east coast of the South Island of New Zealand (Site DSDP 594, at $45^{\circ} 31^{\prime} \mathrm{S}, 174^{\circ} 56^{\prime} \mathrm{E}$ ) at a comparable latitude to the Darwin Crater $\left(42^{\circ} \mathrm{S}\right)$, has been analysed by Heusser \& van de Geer (1994). The pollen sum for the top $40 \mathrm{~m}$ of this core fortunately covers the same region of the oxygen-isotope scale and, thus, provides a comparison with that of the Darwin Crater.

The sediment on the Chatham Rise is predominantly from river transport and, therefore, the depths of core corresponding to the stages of the oxygen-isotope scale are quite different from those of the Darwin Crater. The New Zealand data are plotted in figure $4 \mathrm{~B}$ on the same scale and using the same procedures as those used to develop figure $4 \mathrm{~A}$, except for the above differences in the length of the zone sediments.

Figure $4 \mathrm{~A}$ and $\mathrm{B}$ summarises the percentages of pollen of taxa forming open vegetation (grassland, sedgeland and heath) as distinct from closed forest taxa in the total pollen sums. Both cores have been divided into zones corresponding to the oxygen isotope stages, on the basis of the relative proportions of the major vegetation types of forest and open vegetation. The zones shown in figure $4 \mathrm{~A}$ and $B$ correspond to the stages of the isotopic oxygen deficiency established for the Chatham Rise site (fig. 4C; Nelson et al. 1986).

The correspondence in the Darwin Crater Core between palaeovegetation zones and isotopic oxygen deficit stages is shown in figure $4 \mathrm{~A}$. On this basis, the correspondence between the stages in the Darwin Crater core $(A)$ and the

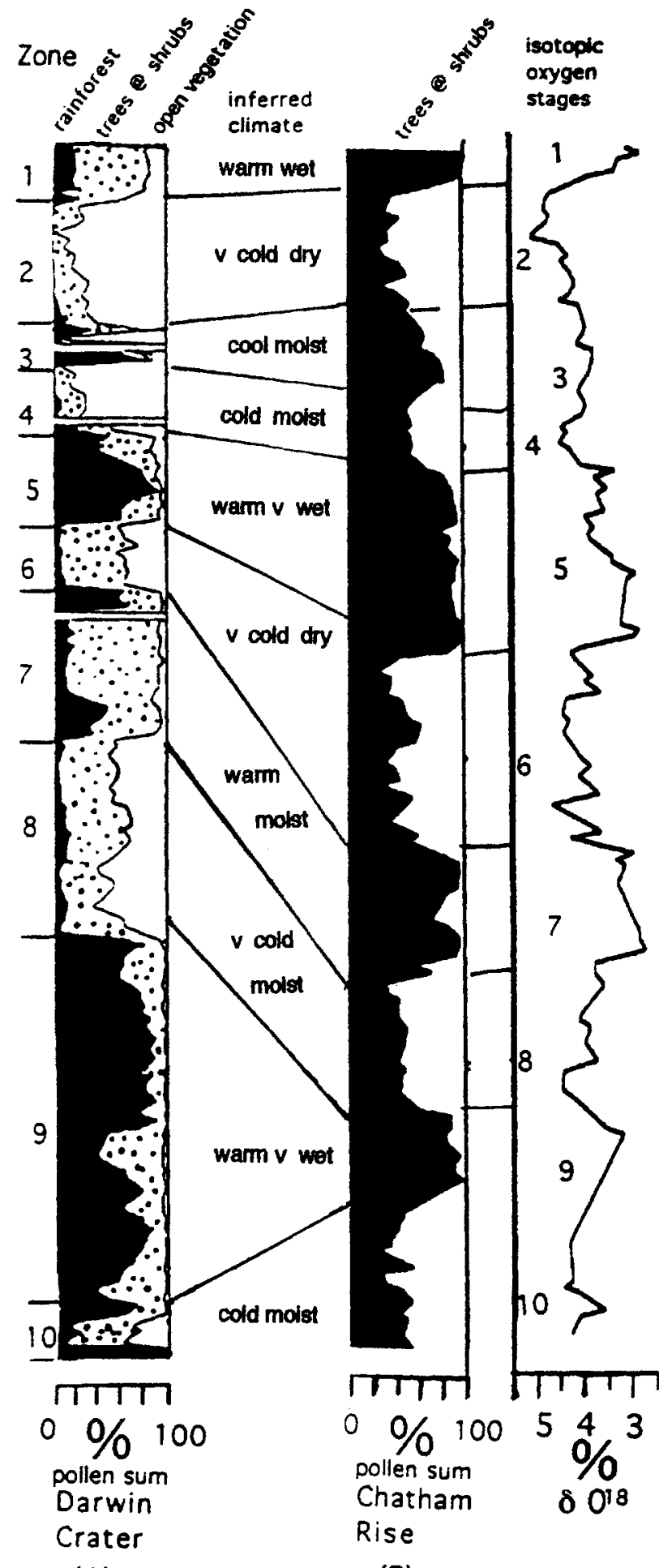

(A)

(B)

FIG. 4 - Summarised pollen sum diagrams of cores from (A) the Darwin Crater, western Tasmania (Colhoun \& van de Geer 1988, 1998); (B) the ocean floor on the Chatham Rise, east of the South Island of New Zealand (Heusser \& van de Geer 1994), and the zones of palaeoclimate and vegetation inferred in both diagrams $(A)$ and $(B)$ aligned with $(C)$ the stages of the isotopic oxygen deficiency derived from the Chatham Rise core (Nelson et al. 1986). 
Chatham Rise core (B) and the $\delta^{18} \mathrm{O}$ data $(\mathrm{C})$ are indicated in figure 4 by lines between the columns. In this interpretation, the stages in the upper $20 \mathrm{~m}$ section of the Darwin Crater core and in the upper $40 \mathrm{~m}$ section of the Chatham Rise core encompass approximately the same span of palaeoclimate $(-350 \mathrm{k}$ rss $)$ or four glacial-interglacial cycles, ignoring the intermediate climates expressed by stages 3 and 4 .

Colhoun $\&$ van de Geer suggested in a recent paper (1998) that stage 6 of the Chatham Rise core might correspond to the combined stages 6,7 and 8 of the earlier interpretation. By ignoring the previous interglacial stage 7 , this would shorten the coverage of the upper $20 \mathrm{~m}$ section of the Darwin Crater core to three glacial cycles.

There appears to be an appreciable increase in the percentage of open vegetation in both the cold, dry and the warm, wet climates during the Last Glacial cycle as compared with previous cycles in the Darwin Crater core. This shift in the proportion of open vegetation during the Last Glacial Cycle is not apparent in the Chatham Rise data.

The above observation can be analysed in detail by returning to the earlier interpretation of the data, where stages correspond to the $\delta^{18} \mathrm{O}$ stages illustrated in figure $4 \mathrm{C}$ (Colhoun \& van de Geer 1988, Colhoun 1989). This is shown in figure $5 \mathrm{~A}$ for the Chatham Rise core and figure $5 \mathrm{~B}$ for the Darwin Crater core, where the mean percentages of open vegetation in the stages corresponding to the $\delta^{18} \mathrm{O}$ stages (Nelson et al. 1986) are plotted for the cold, dry and warm, wet climates.

In figure 4 and the following figures 5 and 6 , the mean percentage of open vegetation in each $100 \mathrm{~mm}$ depth of the Darwin Crater core has been determined for each stage. The means are plotted at the midpoints of each stage. It should be mentioned that a number of hiatuses occur in the upper portion of the Darwin Crater core, due to gravel deposits. These are indicated in figure $4 \mathrm{~A}$ by gaps. On the basis of core depth, the pollen record is missing in $58 \%$ of stage $3,27 \%$ of stage 4 and $37 \%$ of stage 7 . These hiatuses, especially those in stages 3 and 4 , weaken inferences drawn from the data.

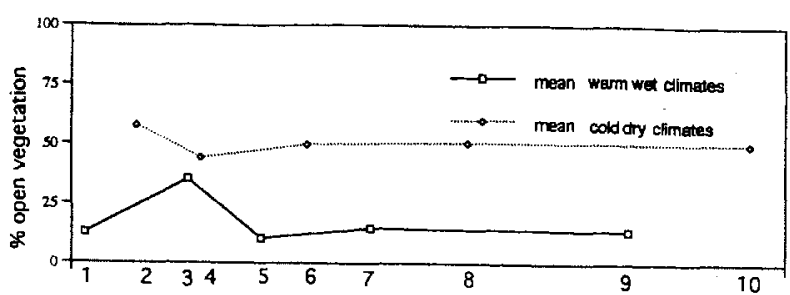

(A) Chatham Rise isotopic oxygen stages

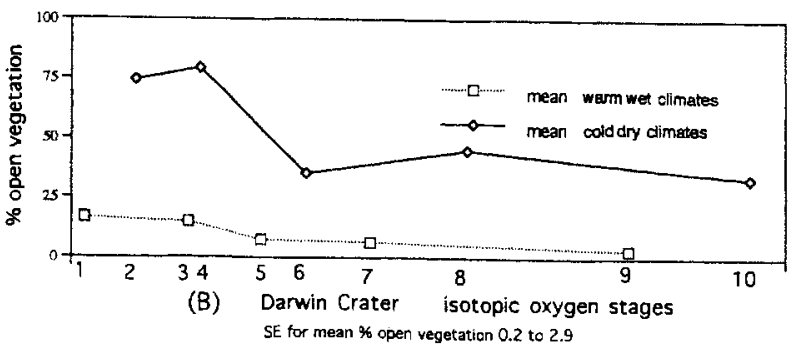

FIG. 5 - The mean percentage of open vegetation in stages of the isotopic oxygen deficit for cold, dry and warm, wet climates inferred from the pollen sums of $(A)$ the Chatham Rise core and $(B)$ the Darwin Crater core.
In the Chatham Rise data (fig. 5A) there is no apparent rise in the levels of open vegetation in stages 1, 3 and 4 . The intermediate nature of the climate of stage 3 is evident. There is a small significant rise in the stage 2 glacial climate. In contrast, in the Darwin Crater data (fig. 5B), the level of open vegetation is effectively double that of the earlier stages. While the increase in stage 3 could be ascribed to the intermediacy of the climate in this stage, as is evident in the Chatham Rise data, the increased levels in the other stages of the last glacial cycle in the Darwin Crater data appear to have no explanation in terms of climate.

The above observations are substantiated by statistical tests on the differences between the mean percentages of open vegetation in sequential groups of stages up the Darwin Crater core within the separate cold, dry and warm, wet climates. These are shown in table $2 \mathrm{~A}$ where the percentage of open vegetation for each $100 \mathrm{~mm}$ of the core has been averaged over each stage or group of stages after arcsine transformation. Within each climatic division, the sequential grouping of stages starting at the lower end of the core is shown in the first column, with the corresponding difference in mean in the second column. The value of the t-test function for this difference is shown in the fourth column. Apart from insignificant differences in the early stages of the cold, dry climates, other differences can be assumed to be real. The scale in the t-values indicates that the observed increase in open vegetation in stage 4 and later stages is real, with probability values several orders of magnitude lower than differences between earlier stages.

As additional support for increased levels of open vegetation during the last glacial cycle in the Darwin Crater data, it should be mentioned that a regression analysis of the percentage of open vegetation on core depth over the cold, dry climates of stages 2 and 4 shows significant relationships. The regression of the percentage of pollen from open vegetation taxa in each $100 \mathrm{~mm}$ sample on the position of the sample up the core in stage 4 shows an increase of $1.9 \%$ per sample with $r^{2}=0.59, P<0.05$, while in stage two the increase is $1.2 \%$ per sample with $r^{2}=0.76, \mathrm{P}<0.001$. There are no significant trends in the earlier stages.

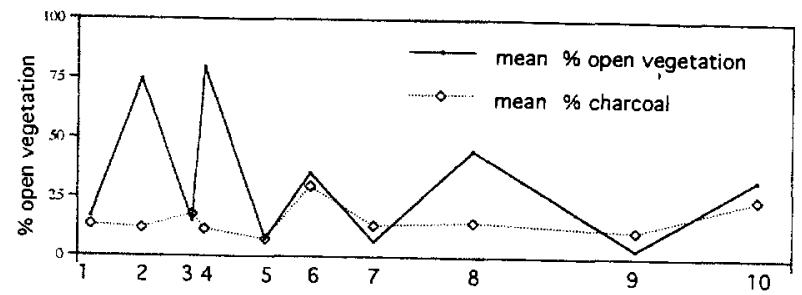

(A) Danwin Crater isotopic oxygen stages

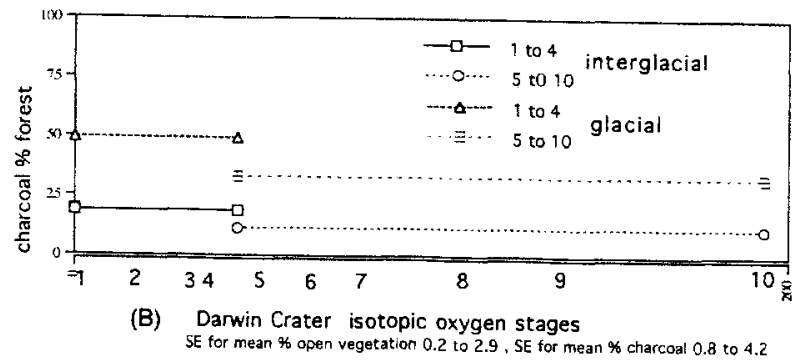

FIG. 6 - (A) The mean percentage of open vegetation and the relative level of charcoal grains $>20 \mu$ in the isotopic oxygen stages of the Darwin Crater core. $(B)$ The mean level of charcoal as a percentage of forest vegetation in the cold, $d r y$ and warm, wet climates of stages 1, 2, 3 and 4, compared with those climates in stages 5 to 10 of the Darwin Crater core. 
TABLE 2

Summary of significance tests

(A) Differences between means of open vegetation in oxygen-isotope stages and groups of stages of the Darwin Crater core (Colhoun 1989); see figure 5B.

\begin{tabular}{lcccclllll}
\hline $\begin{array}{l}\text { Cold, dry climates } \\
\text { Sequential grouping } \\
\text { of stages }\end{array}$ & $\begin{array}{l}\text { Difference } \\
\text { in means }\end{array}$ & $\mathrm{n}$ & $\mathrm{t}$ & $\mathrm{P}$ & $\begin{array}{l}\text { Sequential grouping } \\
\text { of stages }\end{array}$ & $\begin{array}{c}\text { Difference } \\
\text { in means }\end{array}$ & $\mathrm{n}$ & $\mathrm{t}$ & $\mathrm{P}$ \\
$8-10$ & 7 & 32 & 2.1 & 0.05 & $7-9$ & 4.4 & 84 & 6.3 & $<0.001$ \\
$6-(8 \& 10)$ & 4.5 & 42 & 2.4 & 0.05 & $5-(7 \& 9)$ & 4.3 & 97 & 4.2 & $<0.001$ \\
$4-(6,8 \& 10)$ & 23.4 & 50 & 10.9 & $<0.001$ & $3-(5,7 \& 9)$ & 10.7 & 101 & 5.6 & $<0.001$ \\
$2-(4,6,8 \& 10)$ & 16.3 & 63 & 5.5 & $<0.001$ & $1-(3,5,7 \& 9)$ & 11.7 & 107 & 6.7 & $<0.001$ \\
$(2 \& 4)-(6,8 \& 10)$ & 21.2 & 63 & 14 & $<0.001$ & $(1 \& 3)-(5,7 \& 9)$ & 11.6 & 107 & 9.2 & $<0.001$
\end{tabular}

(B) Difference in mean percentage of charcoal levels between oxygen-isotope stages $1-4$ and stages 5-10 of the Darwin Crater core (Colhoun 1989; see figure 6A.

\begin{tabular}{lcccc}
$\begin{array}{l}\text { Grouping of } \\
\text { stages }\end{array}$ & $\begin{array}{c}\text { Difference } \\
\text { in means }\end{array}$ & $\mathrm{n}$ & $\mathrm{t}$ & $\mathrm{P}$ \\
$\begin{array}{l}(1,2,3 \& 4)- \\
(5,6,7,8,9 \& 10)\end{array}$ & 2.83 & 182 & 1.11 & 0.25 \\
\hline
\end{tabular}

(C) Differences in mean percentage of charcoal levels relative to forest levels between groups of isotopic oxygen stages during the Last Glaciation compared with previous cycles; see figure $6 \mathrm{~B}$.

Cold, dry climates

Grouping of

stages

$(2 \& 4)-(6,8 \& 10)$

$\begin{array}{cccccc}\begin{array}{c}\text { Difference } \\ \text { in means }\end{array} & \mathrm{n} & \mathrm{t} & \mathrm{P} & \begin{array}{l}\text { Grouping of } \\ \text { stages }\end{array}\end{array}$

$\begin{array}{llll}7.58 & 69 & 3.63 & <0.001\end{array}$
Warm, wet climates

Grouping of
stages

$(1 \& 3)-(5,7 \& 9)$
Difference $\mathrm{n} \quad \mathrm{t} \quad \mathrm{P}$

in means

$4.33 \quad 111 \quad 2.01$
It should be emphasised that the hiatuses in the pollen record, which are due to gravel deposition in stages 3 and 4 , weaken the strength of the above analysis and the value of the inferences flowing from it. It is possible that another coring of the crater might provide an uninterrupted pollen record.

\section{Charcoal levels}

Colhoun \& van de Geer $(1988,1998)$ scored the number of grains of charcoal $>20 \mu$ in size in each of the $100 \mathrm{~mm}$ sample length of the Darwin Crater core. The mean for all samples in each of the $\delta^{18} 0$ stages has been determined. This provides a comparative measure of wildfire incidence between stages on a nominal scale.

The mean relative charcoal levels for stages in the Darwin Crater core are shown in figure 6A, plotted on the same diagram as the percentage of open vegetation. No relationship between the scales for charcoal and open vegetation is inferred.
There is a trend in figure 6A for higher charcoal levels in glacial climates, levels in $\delta^{18} 0$ stages 6 and 10 being particularly high. Conversely, there is a trend for lower levels in the warm, wet climates. This indicates that conditions drier than at present, as have been proposed for the Last Glaciation (Markgraf et al. 1986), have been duplicated in past glacial episodes. The general level of charcoal throughout the core certainly shows that wildfire has always been a part of Tasmanian environment during the Late Pleistocene.

There does not appear to be any increased level of charcoal accompanying the increased levels of open vegetation during the Last Glacial cycle. This observation is verified statistically in table $2 \mathrm{~B}$, showing the $\mathrm{t}$-test for the difference in the mean level of charcoal over stages 1-4 and the mean of earlier stages 5-10. No significant difference is indicated. However, the more or less average levels of charcoal in stages 1-4 cannot be construed to mean there was no increase in the level of fire during the period, since the amount of woody vegetation necessary to produce charcoal in the surrounding catchment was much reduced during 
the Last Glacial Cycle (38.5\%) compared with $78.8 \%$ earlier.

This is demonstrated in figure 6B, where the mean level of charcoal relative to woody vegetation is plotted for the cold, dry and the warm, wet climates during the Last Glacial Cycle and compared with earlier cycles. Table 2C shows, by t-tests for the differences in means, that the increase in charcoal levels in the cold stages of the Last Glacial Cycle compared with previous cycles is highly significant. The corresponding increase in the warm, wet climates is also significant at $\mathrm{P}=0.04$.

\section{DISCUSSION}

As might be expected, the correspondence between the records of palaeovegetation from the Darwin Crater core $\left(42^{\circ} 19^{\prime} \mathrm{S}\right)$ and from the Chatham Rise core ( $\left.45^{\circ} 31^{\prime} \mathrm{S}\right)$ is very close (fig. 4A, B). Each glacial episode produces a decrease in woody vegetation, especially rainforest species, and an increase in herbaceous vegetation and grassland to about $40-50 \%$ of the total. The shorter interglacial climate periods are marked by a preponderance of forest, with the open vegetation reduced to between 5 and $15 \%$ of the total. As figure $5 \mathrm{~A}, \mathrm{~B}$ indicates, these proportionate levels of open vegetation relative to closed forest remain nearly constant in both warm, wet and cold, dry climates, except in the last glacial cycle of the Darwin Crater core.

Both the New Zealand and Tasmanian data demonstrate greater variation in the responses of the vegetation to the climates of both cold, dry and warm, wet periods during the last cycle as compared with the previous three cycles. A considerable part of this can be attributed to the lower amplitude and shorter periods of the isotope stages 3 and 4. This probably accounts for the intermediate responses of the vegetation during zones 3 and 4 of the New Zealand data in figure $5 \mathrm{~A}$ compared with the longer and more extreme climates of the previous three cycles.

The data for zone 4 of the Darwin Crater core show a major change in the reverse direction to that of zone 4 of the New Zealand data. A massive decrease in the amount of the forest vegetation is indicated. This increase in the amount of open vegetation is maintained in the succeeding zones of 3,2 , and 1 . This parallel shift in the mean values of open vegetation in both the cold, dry and warm, wet climates for the last cycle of the Darwin Crater is not present in the New Zealand data.

During the Last Glacial cycle the record of palaeovegetation in the Darwin Crater core shows a two-fold increase in the proportion of open vegetation in both the cold, dry and the warm, wet climates in comparison with levels in previous cycles (fig. $5 \mathrm{~B}$, table $2 \mathrm{~A}$ ). The proportion of eucalypts relative to rainforest increases and the proportion of rainforest decreases (fig. $4 \mathrm{~A}$ ). The count of carbon particles relative to the amount of woody vegetation increases (fig. 6B, table 2C). The absence of a similar response in New Zealand vegetation infers that the changed responses of the vegetation in Tasmania are the result of increased levels of fire due to human activity.

The simultaneous increase in non-forest vegetation over the Last Glacial cycle in two quite different climates in Tasmania is suggestive of a cause other than climate and is entirely consistent with the response in vegetation which is expected to accompany the presence of Aborigines (Jackson
1968, Bowman \& Jackson 1981, Jackson \& Bowman 1982). As detailed in the introduction, the Aborigines had well-established practices of fire management. They carried fire when on the move and used fire as a tool in hunting, in communication, in warfare and, above all, in controlling game populations by patch-burning vegetation to provide "green-pick" grazing conditions. These activities would produce marked increases in the openness of the vegetation by restricting closed forests and engendering pyrogenic fire tolerant vegetation with fine fuels and vegetative reproduction.

\section{CONCLUSION - A SUGGESTED EARLIER OCCUPATION OF TASMANIA BY THE ABORIGINES}

The Darwin Crater core demonstrates a two-fold increase in the amount of open, non-forest vegetation in the Last Glacial cycle, as compared with levels in the previous three glacial cycles. The divergence from previous patterns commences early in $\delta^{18} 0$ stage 4 . The climate in $\delta^{18} 0$ stage 4 produced near glacial conditions in western Tasmania. Fitzsimons \& Colhoun (1991) and Colhoun \& Fitzsimons (1990) reported evidence of an ice advance, the Chamouni Formation, in the upper King River valley, with till and outwash gravels, laminated silts and plant debris. An age of $61-73 \mathrm{k}$ yrs is suggested for this formation. It is, therefore, understandable that the amount of open vegetation displayed in the Darwin Crater core in this stage would be high. However, the Chatham Rise core shows no parallel increase in open vegetation during $\delta^{18} 0$ stage 4 as compared with previous cycles.

This divergence from previous patterns in the Darwin Crater core continues during the whole of $\delta^{18} 0$ stage 4 and, thereafter, during $\delta^{18} 0$ stages 3,2 and the Holocene.

We know from the anthropological evidence (Cosgrove 1995, Cosgrove et al. 1990) that the Aborigines occupied limestone valleys throughout western and southern Tasmania during the later periods of $\delta^{18} 0$ stage 3 with ${ }^{14} \mathrm{C}$ dating to $34 \mathrm{ka}$ (Cosgrove 1995: fig. 16).

The above palaeovegetation evidence suggests a considerably earlier date for the occupation of Tasmania by the Aborigines. This infers that the ${ }^{14} \mathrm{C}$ dates obtained for the cave and rock-shelter sites are considerable underestimates. Such underestimation by the ${ }^{14} \mathrm{C}$ methodology for palaeomaterial $>30 \mathrm{k}$ yrs in western Tasmania is usual (Colhoun 1986) and is well recognised by Tasmanian palaeoworkers. The groundwater in western and southern Tasmania carries large amounts of humic and humus acids from the peaty surface soil. Such a supply of modern carbon, gradually exchanging with older carbon in buried material, causes these underestimates. It seems likely that Aboriginal occupation of Tasmania may have ocurred as early as $70000 \mathrm{BP}$. This conclusion is supported by a variety of botanical evidence. 


\section{REFERENCES}

BisHOFF, J., 1832: Report to V.D.L. Co. 1828. HISTORY OF AND ACCOUNT OF THE VAN DIEMEN'S LAND CO. Richardson, London: 118.

BOERNER, R.E.J., 1982: Fire and nutrient cycling in temperate ecosystems. Bio Sci. 32: 187-192.

BOwDEN, A.R., 1983: Relict terrestrial dunes: legacies of a former climate in coastal northeastern Tasmania. Z. Geomorphol. N.F. 45: 153-174.

BOWMAN, D.M.J.S. \& JACKSON, W.D., 1981: Vegetation succession in southwest Tasmania. Search 12: 358-362.

Bowman, D.M.J.S. \& BRown, M.J., 1986: Bushfires in Tasmania, a botanical approach to anthropological questions. Archeol. Oceania 21: 166-171.

Bowman, D.M.J.S., MaClean, A.R. \& Crowden, R.K., 1986: Vegetation-soil relations in the lowlands of south-west Tasmania. Aust. J. Ecol. 11: 141-153.

BROWN, M.J. \& BAYLY-STARK, H.J., 1979: Vegetation of Maria Island. Wildl. Div. Tech. Rep. 79/1. NPWS, Hobart.

Brown, M.J. \& PODGer, F., 1982a: On the apparent anomaly between observed and predicted percentages of vegetation types in South-West Tasmania. Aust. J. Ecol. 7: 3-12.

BRown, M.J. \& PODGER, F., 1982b: Floristics and fire regimes of a vegetation sequence from sedgeland-heath to rainforest at Bathurst Harbour, Tasmania. Aust. J. Bot. 30: 659676.

BRown, M.J. \& PODGer, F.D. 1982c: Rainforest-sedgeland transitions. In Felton, K. (Ed.): TASMANIAN RAINFORESTS-RECENT RESEARCH RESULTS. Forest Ecology Research Fund, Hobart: 47-53.

Cheney, A.P., 1981: Fire behaviour. In Gill, A.B., Groves, R.H. \& Nobel, I.R. (Eds): FIRE AND THE AUSTRALIAN BIOTA. Australian Academy of Science, Canberra: 151176.

Colmoun, E.A., 1977: A sequence of Late Quaternary deposits at Pipe Clay Lagoon southeastern Tasmania. Pap. Proc. R. Soc. Tasm. 111: 1-12.

Colmoun, E.A., 1986: Field problems of radiocarbon dating in Tasmania. Pap. Proc. R. Soc. Tasm. 120: 1-6.

Colmoun, E.A., 1989: The Quaternary. In Burrett, C.F. \& Martin, E.L. (Eds): GEOLOGY AND MINERAL RESOURCES OF TASMANIA. Geol. Soc. Aust. Spec. Publ:: 410-418.

Colmoun, E.A. \& Fitzsimons, S.J., 1990: Late Cainozoic glaciation in western Tasmania, Australia. Quat. Sci. Rev. 9: 199-216.

Colmoun, E.A. \& van De Geer, G., 1988: Darwin Crater the King and Linda valleys. In Colhoun, E.A. (Ed.): CAINOZOIC VEGETATION OF TASMANIA. Univ. Newcastle Spec. Pap. Dep. Geogr., Univ. Newcastle: 30 71.

Colhoun, E.A. \& van De Geer, G., 1998: Pollen analysis of $0-20 \mathrm{~m}$ at Darwin Crater western Tasmania, Australia. In Horie, S. (Ed.): International project on palaeolimnology and Late Cainozoic climate. IPPCE 11: 68-89.

Cosgrove, R., 1995: Late Pleistocene behavioural variation and time trends: the case from Tasmania. Archaeol. Oceania 30: 83-104.

Cosgrove, R., Allen, J. \& Marshall, B., 1990: Palaeoccology and Pleistocene human occupation in south central Tasmania. Antiquity 64: 59-78.

DUNCAN, F., 1990: Eucalypts in Tasmania's changing landscape. Tasforests 2: 151-166.

ELLIS, R.C., 1986: The relationship between sub-alpine grassland and forest communities in northern Tasmania. In Barlow B.A. (Ed.): FLORA AND FAUNA OF ALPINE AUSTRALIA AGES AND ORIGINS. CSIRO, Melbourne: $243-248$.
FENSHAM, R.J., 1989: The pre-European vegetation of the Midlands Tasmania: a floristic and historical analysis of vegetation pattern. J. Biogeogr. 16: 29-45.

Fitzsimons, S.J. \& Colmoun E.A., 1991: Pleistocene glaciation of the King Valley western Tasmania, Australia. Quat. Res. 36: 135-156.

FORD, R.J., 1972. A possible impact crater associated with Darwin Glass. Earth Planet. Sci. Lett. 16: 228-230.

FudALI, J. \& ForD, R.J., 1979. Darwin Glass and Darwin Crater — a progress report. Meteoritics 14: 283-296.

Gentner, W., Kirsten, T., Storzer, D. \& Wagner, G.A., 1973: K-Ar and fission track dating of Darwin Crater glass. Earth Planet. Sci. Lett. 20: 203-210.

GilberT, J.M., 1959. Forest succession in the Florentine Valley Tasmania. Pap. Proc. R. Soc. Tasm. 93: 129-151.

HARRIS, S. \& KirKPATRICK, J.B., 1991: The distributions, dynamics and ecological differentiation of Callitris species in Tasmania. Aust. J. Bot. 39: 187-202.

HARWOOD, C.E., 1972. Nutrient studies in south-west Tasmanian vegetation. Unpubl. BSc Hons thesis, Dep. Botany, Univ. Tasm., Hobart.

Henderson, W. \& Wilkins, C.W., 1975: The interaction of bushfires and regetation. Search 16: 130-133.

HeUSSER, L.E. \& VAN DE GEER, G., 1994: Direct correlation of terrestrial and marine palacoclimatic records from four glacial-interglacial cycles - DSDP Site 594. Southwest Pacific. Quat. Sci. Rev. 13: 273-282.

Holland, B.G. \& STEYN, D. G., 1975: Vegetation responses to latitudinal variations in slope angle and aspect. J. Biogeogr. 2: $179-183$.

INGLES, A., 1985: Fire. Environmental Impact statement into the continuation of woodchip exports from Tasmania after 1990. Working paper No. 5. Government Printer, Hobart.

JACKSON, W.D., 1965: Vegetation. In Davies, J.L. (Ed.): ATLAS OF TASMANIA. Lands and Surveys, Hobart: $30-35$

JACKSON, W.D., 1968: Fire, Air, Water and Earth — an elemental ecology of Tasmania. Proc. Ecol. Soc. Aust. 3: 9-16.

JACKSON, W.D., 1977: Nutrient cycling in Tasmanian oligotrophic environments. PROCEEDINGS OF THE SYMPOSIUM ON NUTRIENT CYCLING AND INDIGENOUS FOREST ECOSYSTEMS. CSIRO, Division of Land Resource Management, Perth, WA: 122-123.

JACKSON, W.D., 1981a: The Tasmanian environment. In Jackson, W.D. (Ed.): VEGETATION OF TASMANIA. XIII International Botanical Congress, Sydney: Field Trip 28. Australian Academy of Science, Canberra: 1-10.

JACKSON, W.D., 1981b: Vegetation and fire patterned vegetation. In Jackson, W.D. (Ed.): VEGETATION OF TASMANIA. XIII International Botanical Congress, Sydney: Field Trip 28. Australian Academy of Science, Canberra: 11-35.

JACKSON, W.D., 1981c: Wet Sclerophyll. In Jackson, W.D. (Ed.): VEGETATION OF TASMANIA. XIII International Botanical Congress, Sydney: Field Trip 28. Australian Academy of Science, Canberra: 68-72.

JACKSON, W.D., 1983: Tasmanian rainforest ecology. In Blakers, E.R. \& Robertson, P. (Eds): TASMANIAN'S RAINFORESTS, WHAT FUTURE? Australian Conservation Foundation: 9-39.

JACKSON, W.D., 1999a: Vegetation types. In Reid, J.B., Hill, R.S., Brown, M.J. \& Hovenden, M.J. (Eds): VEGETATION OF TASMANIA. Australian Biological Resources Study, Canberra: 1-10.

JACKSON, W.D., 1999b: The Tasmanian environment. In Reid, J.B., Hill, R.S., Brown, M.J. \& Hovenden, M.J. (Eds): VEGETATION OF TASMANIA. Australian Biological Resources Study, Canberra: 11-34.

JACKSON, W.D., 1999c: Palaeohistory of vegetation change - the last 2 million years. In Reid, J.B., Hill, R.S., Brown, M.J. \& Hovenden, M.J. (Eds): VEGETATION OF 
TASMANIA. Australian Biological Resources Study, Canberra: 64-89.

JACKSON, W.D. \& BOWMAN, D.M.J.S., 1982: Slash burning in Tasmanian dry cucalypt forests, Comment. Aust. For. 1: 63-67.

JACKSON, W.D. \& Brown, M.J., 1999: Pattern and process in the vegetation. . In Reid, J.B., Hill, R.S., Brown, M.J. \& Hovenden, M.J., (Eds) VEGETATION OF TASMANIA. Australian Biological Resources Study, Canberra: $364-$ 387.

Jarman, S.J. \& BROWN, M.J., 1983: A definition of cool temperate rainforest in Tasmania. Search 14: 81-87.

KIERNAN, K., 1989: Muliple glaciation of the upper Franklin Valley, Western Tasmania wilderness world heritage area. Aust. Geogr. Stud. 27: 208-235.

KirKPATRICK, J.B., 1986: Tasmania alpine biogeography and ecology and interpretations of the past. In Barlow, B.A. (Ed.): FLORA AND FAUNA OF ALPINE AUSTRALIA AGES AND ORIGINS. CSIRO, Melbourne: 229-242.

KirKpatrick, J.B. \& Dickinson, K.J.M., 1984: VEGETATION MAP OF TASMANIA 1:500,000. Forestry Commission, Hobart.

Kirkpatrick, J.B., Barker, P., Brown, M.J., Harris, S. \& Mackie, R., 1995: The reservation status of Tasmanian vascular plant communities. Wildl. Sci. Rep. 4. N.P.W.S., Hobart.

La Billardiere, J.J., 1800: AN ACCOUNT OF A VOYAGE IN SEARCH OF LA PERUSE IN THE YEARS 1791, 1792, 1793. Vol. II. London: 26-63.

LING RoTH, H., 1899: THE ABORIGINES OF TASMANIA. 2nd edn. King \& Sons, Halifax, England.

MaCleAN, A.R., 1979: Mineral nutrients in soils and vegetation of sedgeland and heathland communities in south-west Tasmania. Unpubl. BSc Hons. thesis, Dep. Bot., Univ. Tasm., Hobart.

MaCPHAIL, M.K., 1979: Vegetation and climates in southern Tasmania since the last glaciation. Quat. Res. 11: 306341.

Macphail, M.K., 1980: Regeneration processes in Tasmanian forests. Search 11: 184-190.

Markgraf, V., Bradbury, J.P. \& Busby, J.R., 1986: Palaeoclimate in southwestern Tasmania during the last 13,000 years. Palaios 1: 368-380.

Marsden-Smedley, J.B., 1998a: Fire and fuel in Tasmanian buttongrass moorlands: regimes, characteristics, behaviour and management. Unpubl. PhD thesis, Sch. Geogr. Environ. Stud., Univ. Tasm., Hobart.

Marsden-Smedley, J.B., 1998b: Changes in southwest Tasmania fire regimes since the early $1800 \mathrm{~s}$. Pap. Proc. R. Soc. Tasm. 132: 15-29.

Milisgan, J., 1858: Vocabulary of the dialects of some of the aboriginal tribes of Tasmania. Pap. Proc. R. Soc. Tasm. 3: 239-274.

MounT, A.B., 1979: Natural regeneration processes in Tasmanian forests. Search 10: 180-186.

Mount, A.B., 1982: Fire cycles in south-west Tasmania. Search 13: $174-175$.
Nelson, C.S., Hendy, C.H., Cuthbertson, A.M. \& Jarrett, G.R., 1986: Late Quaternary carbonate and isotope stratigraphy, subantarctic site 594, southwest Pacific. In Kennett, J.P. \& van der Borch, C.C. (Eds): INITIAL REPORTS OF THE DEEP SEA DRILLING PROJECT. U.S. Gov. Pr. Office Washington D.C.: 1425-1436.

Nicolls, K.D., 1958: Acolian deposits in river valleys in Tasmania. Aust. J. Sci. 21: 50-51

Noble, I.R. \& SLATyer, R.O., 1981: Concepts and models of succession in vascular plant communities subject to recurrent fire. In Gill, A.M., Groves, R.H. \& Noble, I.R. (Eds): FIRE AND AUSTRALIAN BIOTA. Australian Academy of Science, Canberra: 311-335.

Nunez, M., 1978: The radiation index of dryness in Tasmania. Aust. Geogr. Stud. 16: 126-135.

PLOMLEY, N.J.B., 1966: FRIENDLYMISSION, THE TASMANLAN JOURNALS AND PAPERS OF GEORGE AUGUSTUS ROBINSON 1829-1834. Tasmanian Historical Research Association, Halstead, Kingsgrove, NSW.

Podger, F.D., BirD, T. \& Brown, M.J., 1989: Human activity, fire and change in the forest at Hogsback Plain, southern Tasmania. In Frawley, K.J. \& Semple, N. (Eds): AUSTRALIA'S EVER CHANGING FORESTS. Australian Defence Force Academy, ACT.

READ, J., 1985: Photosynthetic and growth responses to different light regimes of the major canopy species of Tasmanian cool temperate rainforest. Aust. J. Ecol. 10: 327-334.

Reid, J.B. \& PotTs, B.M. 1999: Eucalypt biology. In Reid, J.B., Hill, R.S., Brown, M.J. \& Hovenden, M.J. (Eds): VEGETATION OF TASMANIA. Australian Biological Resources Study, Canberra: 203-228.

Reid, J.B., Hill, R.S., Brown, M.J. \& Hovenden, M.J. (Eds), 1999: THE VEGETATION OF TASMANIA. Australian Biological Resources Study, Canberra: 440 pp.

R.F.A., 1996: TASMANIAN-COMMONWEALTH REGIONAL FOREST AGREEMENT. Environment and Heritage Report, Vol. 1. Background Report Part C. Tasmanian Public Land Use Commission: 210 pp.

Scott, P., 1956: Variability of annual rainfall in Tasmania. Pap. Proc. R. Soc. Tasm. 90: 499-557.

Sigleo, W.R. \& Coulhoun, E.A., 1981: A short pollen diagram from Crown Lagoon in the Midlands of Tasmania Pap. Proc. R. Soc. Tasm. 115: 181-188.

Sigleo, W.R. \& Colhoun, E.A., 1982: Terrestrial dunes, man and the Late Quaternary environment in southern Tasmania. Paleogeog. Paleoclim. Paleoecol. 39: 87-121.

Withers, J. \& Ashton, D.H., 1977: Studies on the status of unburnt Eucalyptus Woodland at Ocean Grove, Victoria. I. The structure and regeneration. Aust. J. Bot. 25: 623637.

(accepted 25 January 1999) 